\title{
Determinan Faktor Struktur Modal pada Perusahaan Properti dan Real Estate yang Terdaftar di Bursa Efek Indonesia pada Tahun 2013-2018
}

\author{
(Determinant Factors of Capital Structure in Property and Real Estate Companies Listed \\ in Indonesia Stock Exchange in 2013-2018)
}

\author{
Mohammad Zidni Rizky*, R. Aditya Kristamtomo Putra \\ Universitas Singaperbangsa Karawang 1, Karawang, Indonesia \\ E-mail: zidniriz@gmail.com
}

\begin{abstract}
Abstrak
Penelitian ini bertujuan mengetahui gambaran dan determinan faktor struktur modal pada perusahaan properti dan real estate yang terdaftar di Bursa Efek Indonesia pada tahun 2013-2018. Variabel independen penelitian yaitu struktur aktiva, profitabilitas, pertumbuhan perusahaan, ukuran perusahaan dan likuiditas, sedangkan variabel dependen yaitu struktur modal. Sampel diambil melalui purposive sampling, sehingga didapatkan sejumlah 29 perusahaan. Teknik analisis data memakai regresi linear berganda data panel Random Effect Model. Hasil dari penelitian ini yaitu secara bersama-sama struktur aktiva, profitabilitas, pertumbuhan perusahaan, ukuran perusahaan dan likuiditas berpengaruh secara signifikan terhadap struktur modal. Secara parsial struktur aktiva berpengaruh negatif dan tidak signifikan signifikan terhadap struktur modal, profitabilitas berpengaruh negatif dan signifikan terhadap struktur modal, pertumbuhan perusahaan berpengaruh positif dan signifikan terhadap struktur modal, ukuran perusahaan berpengaruh positif dan tidak signifikan terhadap struktur modal, dan likuiditas berpengaruh negatif dan signifikan terhadap struktur modal.
\end{abstract}

Kata Kunci: struktur modal, struktur aktiva, profitabilitas, pertumbuhan perusahaan, ukuran perusahaan, likuiditas.

\begin{abstract}
The aim of this study was to analyze the determinant factors of capital structure on property and real estate companies listed in Indonesia Stock Exchange in 2013-2018. The independent variables used in this study were assets structure, profitability, firm growth, firm size, and liquidity, whereas the dependent variable was capital structure. This study used purposive sampling so there were 29 companies being analyzed. The data was analyzed using panel data multiple linear regression method with Random-effects Model approach. This study found that simultaneously, the assets structure, profitability, firm growth, firm size, and liquidity could significantly affecting the capital structure of the companies. Partially, the assets structure and liquiditty negative and insingificant effect, profitabillity has negative and signficant effect, firm growth has positive and significant efect, and firm size has positive and insignificant effect.
\end{abstract}

Keywords: capital structure, assets structure, profitability, firm growth, firm size, liquidity.

\section{Pendahuluan}

Situasi ekonomi saat ini memberikan dampak terhadap perekonomian nasional membuat semakin ketatnya dunia persaingan bisnis. Dalam menghadapi persaingan tersebut, perusahaan dituntut bijak dalam menggunakan dana perusahaan dan harus memiliki strategi dalam mencari dana untuk pembiayaan investasi Herlisnawati, Insani, \& Indrayono (2015).

Properti dan real estate dianggap pilihan investasi bisnis yang menjanjikan. Lahan yang semakin sempit serta pertumbuhan penduduk yang terus menerus membuat harga menjadi semakin meningkat. Permintaan terhadap properti dan real estate berbanding terbalik dengan stok yang ada, ini merupakan adanya peluang sangat besar. Maka dari itu bisnis ini banyak dilirik oleh investor dalam negeri maupun luar negeri Ariani \& Wiagustini (2017).

Sektor industri properti dan real estate mempunyai risiko tinggi dan tidak mudah untuk diramalkan. Tidak mudah diramalkan karena ketika ekonomi bertumbuh maka sektor mengalami kenaikan dan bahkan melebihi persediaan begitupun sebaliknya. Berisiko tinggi karena sumber dana utama yaitu peminjaman kepada bank, sementara perusahaan properti dan real estate memiliki aset tetap yaitu tahan dan bangunan. Meskipun aset tetap ini bisa digunakan untuk membayar tetapi aset tersebut tidak mudah menjualnya dengan waktu yang singkat, mengakibatkan banyak perusahaan properti dan real estate kesulitan melunasi hutangnya tepat pada waktunya. Hal lain yang menyebabkan perusahaan ini tidak dapat membayar hutangnya dalam waktu yang ditentukan yaitu karena terjadi penurunan penjualan. Penurunan ini dikarenakan terjadi spekuasi terhadap tahan dan bangunan, mengakibatkan harga jual dari bangunan tersebut menjadi tinggi. Karena tingginya harga tanah dan bangunan yang diikuti oleh kelebihan stok mengakibatkan penjualan dibawah target yang diharapkan Rifai (2015). Namun pada kenyataanya bisnis properti dan real estate banyak peminatnya.

Hal yang perlu diperhatikan perusahaan ialah keputusan pendanaan. Keputusan pendanaan yaitu analisis pendanaan perusahaan melalui hutang dan modal yang diperuntukan untuk menjalankan operasional perusahaan baik berupa aset tetap maupun modal kerja Sarah (2018). Dari kedua sumber pendanaan itu terbentuk struktur modal.

\footnotetext{
* Corresponding author
} 
Hal lain mesti dilihat perusahaan ialah struktur modal sebab naik turunnya struktur modal akan berdampak kepada keuangan perusahaan Riyanto (2011). Tugas utama dari direktur dan manajer keuangan untuk menentukan besaran proporsi modal dan hutang yang optimal untuk kegiatan operasional perusahaan Aditya \& Imo Gandakusuma (2015). Dengan mengoptimalkan harga saham maka struktur modal akan menjadi. Struktur modal dipengaruhi beberapa variabel, penelitian dari Sarah (2018) fokus terhadap lima variabel keuangan kinerja perusahaan yaitu FAR, Size, Growth, CR dan ROA.

Sumber yang mudah diterima untuk menjamin pinjaman bank adalah Struktur Aktiva karena dapat mengurangi risiko dari bank ataupun pihak yang dipinjamkan. Mengartikan struktur aktiva mempunyai peranan yang signifikan untuk mendefinisikan struktur modal. Perusahaan dengan struktur aktivanya tinggi maka dapat dipercaya untuk menjamin Batubara, Topowijono, \& Z.A. (2017). Dalam penelitian struktur aktiva dengan struktur modal Niztiar \& Muharam (2013) memiliki kesimpulan bahwa" adanya pengaruh negative dari struktur aktiva dengan struktur modal." Thi Phuong Nhung, Phuong Lien, \& Thi Thu Hang (2017) berkesimpulan bahwa adanya pengaruh positif.

Laba yang besar yang dimiliki perusahaan akan lebih mempergunakan dana yang dimiliki oleh perusahaan karena perusahaan memiliki laba ditahan dan akan menghindari penggunaan hutang. Dalam penelitian profitabilitas dengan struktur aktiva Zerriaa \& Noubbigh (2015) memiliki kesimpulan bahwa adanya pengaruh positif dari profitabilitas dengan struktur modal. Sedangkan Dakua (2019) berkesimpulan bahwa profitabilitas mempunyai pengaruh negatif.

Aset perusahaan akan naik ketika perusahaan bertumbuh tinggi. Seperti menurut Brigham dan Houston (2011:189) dalam Maryanti (2016) berpendapat “dana eksternal dibutuhkan oleh perusahaan ketika pertumbuhan perusahaan tinggi." Dalam penelitian pertumbuhan perusahaan dengan struktur modal Ariani \& Wiagustini (2017) berkesimpulan bahwa "pertumbuhan perusahaan mempunyai pengaruh positif."

Perusahaan cenderung memperbesar hutangnya ketika ukuran dari suatu perusahaan tersebut besar. Dalam penelitian ukuran perusahaan dengan struktur modal Batubara et al. (2017) memiliki kesimpulan bahwa ada pengaruh positif ukuran perusahaan pada struktur modal. Sementara Djazuli, Choiriyah, \& Anggraini (2019) berkesimpulan bahwa ukuran perusahaan mempunyai pengaruh negatif.

Likuiditas dapat diartikan sebagai tolak ukur bagi perusahaan untuk melunasi kewajiban jangka pendeknya. Dalam penelitian Aditya \& Imo Gandakusuma (2015) memiliki kesimpulan bahwa ada pengaruh negatif dari likuiditas terhadap struktur modal. Sedangkan Noor Saarani \& Shahadan (2013) berkesimpulan bahwa likuiditas mempunyai pengaruh positif.

Berdasarkan penjabaran diatas peneliti tertarik untuk meneliti tentang "Determinan Faktor Struktur Modal pada Perusahaan Properti dan Real Estate yang Terdaftar di BEI pada Tahun 2013-2018”.

\section{Hipotesis}

H1 : Struktur Aktiva, Profitabilitas, Pertumbuhan Perusahaan, Ukuran Perusahaan dan Likuiditas berpengaruh secara simultan terhadap Struktur Modal.

\section{Kajian Teori}

Modigliani \& Miller Theory, Trade-off Theory, Pecking Order Theory, Signaling Theory dan Struktur Modal

Sutrisno (2013:266) menyatakan teori struktur modal modern ada 2 jenis yakni Modigliani \& Miller Theory (Teori MM) dengan dan tanpa pajak. Karena adanya proses arbitrase menjadikan nilai perusahaan yang punya atau tidak mempunyai hutang akan sama. Proses arbitrase ini lebih disukai oleh para penanam modal karena investasinya sama tetapi mendapat keuntungan yang lebih besar. Pada kenyataanya pajak ditetapkan di setiap negara. Pada teori ini perusahaan sebaiknya memaksimalkan penggunaan hutang, tetapi pada kenyataanya ini tidak realistis karena hutang yang tinggi akan membuat beban perusahaan menjadi tinggi.

Trade-off Theory mengasumsikan bahwa perusahaan memilih untuk berhutang sampai pada tahap perusahaan kesulitan untuk melunasi hutangnya. Menurut Brigham dan Houston (2011:183) dalam Ariani \& Wiagustini (2017) berpendapat bahwa perusahaan akan menghemat pajak dengan cara berhutang maka masalah yang akan timbul adalah risiko kebangkrutan.

Pecking Order Theory berdasarkan Myers (1984) dalam Noor Saarani \& Shahadan (2013) berpendapat dana dari internal akan cenderung digunakan oleh perusahaan. Pada teori ini perusahaan yang cenderung menggunakan dana internal ketika tingkat profitbilitasnya tinggi sehingga memiliki sedikit hutang.

Struktur modal merupakan penggunaan sinyal yang digunakan oleh perusahaan. Menurut Brigham dan Houston (2011:186) dalam Ariani \& Wiagustini (2017) menyatakan bahwa "manajeman perusahaan akan memberikan sinyal kepada para penanam modal agar dapat melihat dan menilai prospek dari perusahaan. Ini yang dinamakan Signaling Theory."

Saham biasa, saham preferen dan hutang merupakan proporsi dari struktur modal James Van Horne \& Jr (2012). Struktur modal biasanya digunakan sebagai alat pengukur sebab dengan begitu struktur modal dapat diukur Prayogo (2016). Pada dasarnya penggunaan hutang secara keseluruhan untuk meningkatkan nilai perusahaan sangat jarang ditemui, karena hutang yang tinggi akan menyebabkan kewajiban yang harus dilunasi akan semakin tinggi Ariani \& Wiagustini (2017). Dengan demikian perusahaan harus menggabungkan antara modal perusahaan dengan hutang dari luar sehingga tidak merugikan perusahaan.

\section{Faktor - faktor Pembentuk Struktur Modal \\ Struktur Aktiva (FAR)}

Struktur aktiva (FAR) yaitu proporsi dari aset tetap dengan total aset. Struktur aktiva adalah penentu seberapa besar komponen aktiva dialokasikan untuk aktiva lancer dan aktiva tetap Putri (2014). Tingginya struktur aktiva menunjukkan bahwa perusahaan lebih mudah mendapat pinjaman hutang karena struktur aktiva bisa dijadikan jaminan Batubara et al. (2017). Pengukuran struktur aktiva menggunakan rumus sebagai berikut : 


$$
F A R=\frac{\text { Total Fixe Asset }}{\text { Total Asset }}
$$

Profitabilitas (ROA)

Profitabilitas adalah kemampuan untuk menghasilkan laba. Menurut Aditya \& Imo Gandakusuma (2015) menyatakan bahwa "profitabilitas merupakan rasio dalam mengevaluasi investasi atas aset perusahaan untuk mendapatkan profit usaha." Perusahaan dengan profit tinggi maka akan memanfaatkan dana perusahaan dibandingkan meminjam dana dari luar perusahaan karena menghemat pengeluaran perusahaan Ariani \& Wiagustini (2017). Pengukuran profitabilitas menggunakan rumus sebagai berikut :

$$
R O A=\frac{\text { Net Income }}{\text { Total Asset }}
$$

\section{Pertumbuhan Perusahaan (Growth)}

Setiap perusahaan berusaha mencapai pertumbuhan yang tinggi dari periode ke periode karena pertumbuhan perusahaan menggambarkan perkembangan dari suatu perusahaan. righam dan Houston (2011:189) dalam Maryanti (2016) berpendapat bahwa modal dari luar perusahaan dimanfaatkan guna mempercepat pertumbuhan. Pengukuran pertumbuhan perusahaan sebagai berikut :

$$
A G=\frac{\text { Total Asset } t-\text { Total Asset } t-1}{\text { Total Asset } t-1} \times 100
$$

Ukuran Perusahaan (Size)

Besar atau kecilnya suatu perusahaan merupakan merujuk pada size firm. Menurut Batubara et al. (2017) berpendapat bahwa "besarnya ukuran dari suatu perusahaan akan terstimulus untuk memperbesar hutang." Pengukuran ukuran perusahaan sebagai berikut :

\section{Ukuran Perusahaan $=\ln$ Total Assets}

Likuiditas (CR)

Menurut Prayogo (2016) "likuiditas merupakan ukuran kesanggupan perusahaan untuk melunasi hutang jangka pendek. Pengukuran likuiditas sebagai berikut" :

$$
\text { Current Ratio }=\frac{\text { Current Asset }}{\text { Current Liabilities }}
$$

\section{Metode}

\section{Desain Penelitian}

Kuantitatif adalah desain dari penelitian ini. Menurut Sugiyono (2014:13) metode penelitian yang digunakan sebagai pengujian dari hipotesis yang ada, meneliti dengan data populasi atau sampel yang bersifat kuantitatif.

\section{Jenis dan Sumber Data}

Data internal adalah jenis data dalam penelitian ini, berupa laporan keuangan. Sedangkan sumber data didapat dari website PT BEI (www.idx.com) atau website resmi perusahaan.

\section{Populasi dan Sampel}

Populasi penelitian yaitu Perusahaan properti dan real estate yang terdaftar di BEI pada tahun 2013-2018. Sampel memakai metode purposive. Purposive sampling adalah pengambilan sampel dengan kriteria tertentu Jogiyanto (2009:61). Kriterianya yaitu Perusahaan properti dan real estate yang menerbitkan laporan keuangan yang sudah diaudit tahun 2013-2018.

\section{Metode Analisis Data}

Analisis deskriptif verifikatif adalah metode analisis data yang dipakai dalam penelitian ini dan memakai software Eviews 10 dan Random Effect Model adalah model terbaik yang digunakan dalam penelitian ini.

Basuki \& Nano Prawoto (2016:276) dalam Wulandari \& Zulhaimi (2017) berpendapat bahwa estimasi model regresi data panel dapat dilakukan dengan tiga pendekatan yaitu Common Effect Model, Fixed Effect Model dan Random Effect Model. Adapun untuk memilih model terbaik, terdapat beberapa pengujian.

Pertama yaitu Uji Chow untuk menentukan model terbaik antara Common Effect Model dengan Fixed Effect Model. Hipotesis yang digunakan yaitu :

\section{$H_{0} \quad$ : Common Effect Model \\ $H_{1} \quad$ :Fixed Effect Model}

Terima $\quad H_{0}$ bila probabilitas cross section Chi-square $\geq \alpha$ (0.05). Tolak $H_{0}$ bila probabilitas Chi-square $<\alpha(0.05)$.

Kedua yaitu Uji Hausman untuk menentukan model terbaik antara Fixed Effect Model dengan Random Effect Model. Hipotesis yang digunakan yaitu :

\section{$H_{0} \quad$ :Random Effect Model \\ $H_{1}$ : Fixed Effect Model}

Terima $\quad H_{0} \quad$ bila probabilitas cross section Chi-square $\geq \alpha$ (0.05). Tolak $H_{0}$ bila probabilitas Chi-square $<\alpha(0.05)$.

Ketiga yaitu Uji Lagrange Multiplier untuk menentukan model terbaik antara Common Effect Model dengan Random Effect Model.

Hipotesis yang digunakan yaitu :

\section{$H_{0}$ : Common Effect Model \\ $H_{1} \quad$ :Random Effect Model}

Terima $H_{0}$ bila probabilitas $\mathrm{F} \geq \alpha(0.05)$. Tolak $H_{0}$ bila probabilitas $\mathrm{F}<\alpha(0.05)$.

\section{Hasil dan Pembahasan}

\section{Analisis Statistik Deskriptif}

Analisis statistik deskriptif ini dipakai untuk melihat mean, nilai maksimal, nilai minimal, standar deviasi dan data observasi antar variabel. Dapat dilihat sebagai berikut :

Tabel 1. Analisis Statistik Deskriptif

\begin{tabular}{ccccccc}
\hline Minimum & -3.361220 & -0.241597 & -0.087951 & -0.196490 & 14.94659 & 0.207727 \\
Std. Dev. & 0.642371 & 0.086262 & 0.047741 & 0.114198 & 4.164984 & 1.715001 \\
Observations & 132 & 132 & 132 & 132 & 132 & 132 \\
\hline
\end{tabular}




\begin{tabular}{ccccccc}
\hline & LOGDER & FAR & ROA & GROWTH & SIZE & CR \\
\hline Mean & -0.394936 & 0.067200 & 0.046479 & 0.098260 & 26.29535 & 2.456093 \\
Maximum & 0.807309 & 0.350011 & 0.221653 & 0.612342 & 31.58421 & 10.06451 \\
\hline
\end{tabular}

Sumber : Diolah peneliti dari Eviews 10, 2020

Tabel 1. menunjukkan bahwa variabel dependen Struktur Modal (Y) jumlah observasi sebanyak 132, nilai maksimum 0.807309 , nilai minimum sebesar -3.361220 , mean yaitu -0.394936 dan standar deviasi yaitu 0.642371. Dapat dilihat standar deviasi lebih besar dari mean, mengartikan kurang meratanya persebaran data sehingga data menjadi kurang baik. Sebab data kurang baik karena terdapat perbedaan strategi dalam proporsi pendanaan struktur modal antar perusahaan Rosyid, Aziz, \& Triwahyuningtyas (2010).

Variabel Struktur Aktiva (X1) jumlah observasi sebanyak 132, nilai maksimum sebesar 0.350011 , nilai minimum sebesar -0.241597 , mean sebesar 0.067200, standar deviasi sebesar 0.086262. Dapat dilihat standar deviasi $>$ mean, mengartikan kurang meratanya persebaran data sehingga data menjadi kurang baik. Sebab data kurang baik karena terdapat perbedaan aset tetap yang dimiliki perusahaan properti dan real estate Tijow, Sabijono, \& Tirayoh (2018).

Variabel Profitabilitas (X2) jumlah observasi sebanyak 132, nilai maksimum sebesar 0.221653 , nilai minimum sebesar -0.087951, mean sebesar 0.046479, standar deviasi sebesar 0.047741. Dapat dilihat standar deviasi > mean, mengartikan kurang meratanya persebaran data sehingga data menjadi kurang baik. Sebab data kurang baik karena terdapat perbedaan strategi yang dimiliki oleh setiap perusahaan dalam mendapatkan keuntungan dan perbedaan aset perusahaan properti dan real estate Salempang, Sondakh, \& Pusung (2016).

Variabel Pertumbuhan Perusahaan (X3) jumlah observasi sebanyak 132, nilai maksimum sebesar 0.612342, nilai minimum sebesar 0.196490, mean sebesar 0.098260, standar deviasi sebesar 0.114198. Dapat dilihat standar deviasi > mean, mengartikan kurang meratanya persebaran data sehingga data menjadi kurang baik karena terdapat perbedaan strategi dari setiap perusahaan, terdapat perusahaan memilih untuk bertumbuh secara cepat, ada juga perusahaan yang menahan pertumbuhan tidak begitu cepat, jika pertumbuhan aset dari period ke periode tinggi, maka risiko yang ditanggung investor akan menjadi tinggi begitu pula sebaliknya Astuti, Ritonga, \& A (2014).

Variabel Ukuran Perusahaan (X4) jumlah observasi sebanyak 132, nilai maksimum sebesar 31.58421 , nilai minimum sebesar, 14.94659, mean sebesar 26.29535, standar deviasi sebesar 4.164984. Dapat dilihat standar deviasi < mean, mengartikan bahwa tidak terdapat penyimpangan data menunjukkan hasil yang baik karena terdapat kesamaaan strategi yang dilakukan setiap perusahaan, sehingga perusahaan yang memiliki ukuran besar akan dikenal publik mengakibatkan investor akan tertarik berinvestasi dan akan menaikan nilai perusahaan Novari \& Lestari (2016).

Variabel Likuiditas (X5) jumlah observasi sebanyak 132, nilai maksimum sebesar 10.06451, nilai minimum sebesar
0.207727, mean sebesar 2.456093, standar deviasi sebesar 1.715001. Dapat dilihat standar deviasi < mean, mengartikan bahwa tidak terdapat penyimpangan data menunjukkan hasil yang baik karena terdapat kesamaan strategi yang dilakukan oleh perusahaan, sehingga perusahaan dengan likuiditas tinggi dapat dipastikan memiliki hutangnya sedikit dikarenakan aset lancar perusahaan mampu menutupi kebutuhan dari perusahaan Mufidah, Ulupui, \& Prihatni (2018).

\section{Analisis Regresi Linear Berganda}

Pemilihan Model Data Panel

Uji Chow

Digunakan untuk melihat estimasi model terbaik dari Common Effect Model dengan Fixed Effect Model.

Tabel 2. Hasil Uji Chow

Redundant Fixed Effects Tests

Equation: Untitled

Test cross-section fixed effects

\begin{tabular}{cccc} 
Effects Test & Statistic & d.f. & Prob. \\
$\begin{array}{c}\text { Cross-section F } \\
\text { Cross-section Chi- } \\
\text { square }\end{array}$ & 20.449451 & $(21,105)$ & 0.0000 \\
& 214.797824 & 21 & 0.0000 \\
\hline
\end{tabular}

Sumber : Diolah peneliti dari Eviews 10, 2020

Dari tabel 2. Diketahui bahwa nilai probabilitas dari Cross section Chi-square sebesar 0.0000. Dikarenakan probabilitas $<0.05$ maka tolak $H_{0}$, dapat disimpulkan bahwa Fixed Effect Model merupakan estimasi model terbaik.

Uji Hausman

Digunakan untuk melihat estimasi model terbaik dari Random Effect Model dengan Fixed Effect Model.

Tabel 3. Hasil Uji Hausman

Correlated Random Effects - Hausman Test

Equation: Untitled

Test cross-section random effects

\begin{tabular}{cccc} 
& Chi-Sq. & & \\
$\begin{array}{c}\text { Test Summary } \\
\begin{array}{c}\text { Cross-section } \\
\text { random }\end{array}\end{array}$ & Statistic & Chi-Sq. d.f. & Prob \\
& 1.621385 & 5 & 0.8987 \\
\hline
\end{tabular}

Sumber : Diolah peneliti dari Eviews 10, 2020

Dari tabel 3. Diketahui bahwa nilai probabilitas Chi-square sebesar $0.8987 \geq 0.05$ maka terima $H_{0}$, dapat disimpulkan bahwa Random Effect Model merupakan estimasi model terbaik.

\section{Uji Lagrange Multiplier}

Digunakan untuk melihat estimasi terbaik dari Common Effect Model dengan Random Effect Model. 
Tabel 4. Hasil Uji Lagrange Multiplier

Lagrange multiplier (LM) test for panel data

Date: 05/12/20 Time: 21:05

Sample: 20132018

Total panel observations: 132

Probability in ()

\begin{tabular}{cccc}
$\begin{array}{c}\text { Null (no rand. } \\
\text { effect) } \\
\text { Alternative }\end{array}$ & $\begin{array}{c}\text { Cross-section } \\
\text { One-sided }\end{array}$ & $\begin{array}{c}\text { Period } \\
\text { One-sided }\end{array}$ & Both \\
Breusch-Pagan & 176.3240 & 2.341612 & 178.6656 \\
Honda & $(0.0000)$ & $(0.1260)$ & $(0.0000)$ \\
& 13.27870 & -1.530233 & 8.307424 \\
King-Wu & $(0.0000)$ & $(0.9370)$ & $(0.0000)$ \\
& 13.27870 & -1.530233 & 4.447851 \\
GHM & $(0.0000)$ & $(0.9370)$ & $(0.0000)$ \\
& -- & -- & 176.3240 \\
\hline
\end{tabular}

Sumber : Diolah peneliti dari Eviews 10, 2020

Dari tabel 4. Diketahui bahwa nilai probabilitas BreuschPagan sebesar $0.0000<0.05$ maka tolak $H_{0}$, dapat disimpulakan bahwa Random Effect Model merupakan estimasi model terbaik.

Dari ketiga estimasi model data panel dapat dilihat bahwa Uji Chow model terbaiknya adalah Fixed Effect Model. Uji Hausman model terbaiknya adalah Random Effect Model. Dan Uji Lagrange Multiplier model terbaiknya adalah Random Effect Model. Maka dapat disimpulkan dari ketiga pengujian model data panel Random Effect Model adalah estimasi model terbaik.

Menggunakan model Random Effect Model data panel dan berguna untuk melihat hasil persamaan dari determinan variabel FAR, ROA, Growth, Size, CR terhadap DER.

Tabel 5. Analisis Regresi Linear Berganda

\begin{tabular}{ccccc}
\hline Variable & Coefficient & Std. Error & t-Statistic & Prob \\
\hline C & -0.347111 & 0.335600 & -1.034301 & 0.3030 \\
FAR & -0.949322 & 0.572579 & -1.657975 & 0.0998 \\
ROA & -1.745852 & 0.857364 & -2.036303 & 0.0438 \\
GROWTH & 1.348891 & 0.259959 & 5.188867 & 0.0000 \\
SIZE & 0.018351 & 0.026797 & 0.684825 & 0.4947 \\
CR & -0.099751 & 0.028428 & -3.508848 & 0.0006
\end{tabular}

Sumber : Diolah peneliti dari Eviews 10, 2020

Dari tabel 5. menghasilkan persamaan regresi linear berganda data panel:

$\mathrm{Y}=-0.347111-0.949322 \mathrm{X} 1-1.745852 \mathrm{X} 2+1.348891 \mathrm{X} 3+$ $0.018351 X 4-0.099751 X 5$

Berdasarkan persamaan regresi linear berganda data panel diatas dapat diinterpretasikan sebagai berikut :

1. Struktur Aktiva, Profitabilitas, Pertumbuhan Perusahaan, Ukuran Perusahaan, Likuiditas bernilai konstanta yang bernilai negatif yaitu 0.347111 artinya Struktur Modal akan turun yaitu 0.347111 .
2. Struktur Aktiva (FAR) bernilai koefisien yang bernilai negatif sebesar 0.949322 mengarikan variabel FAR mengalami peningkatan $1 \%$ dan variabel independen lain konstan artinya struktur modal akan turun sebesar 0.949322 .

3. Profitabilitas (ROA) memiliki nilai koefisien yang bernilai negatif sebesar 1.745852 mengartikan variabel ROA mengalami peningkatan $1 \%$ dan variabel independen konstan artinya struktur modal akan turun sebesar 1.745852 .

4. Pertumbuhan Perusahaan (Growth) memiliki nilai koefisien yang bernilai positif sebesar 1.348891 variabel Growth mengalami peningkatan 1\% dan variabel independen konstan artinya struktur modal akan naik sebesar 1.348891 .

5. Ukuran Perusahaan (Size) bernilai koefisien yang bernilai positif yaitu 0.018351 mengartikan variabel Size mengalami peningkatan $1 \%$ dan variabel independen konstan artinya struktur modal akan naik sebesar 0.018351.

6. Likuiditas (CR) bernilai koefisien negatif yaitu 0.099751 mengartikan variabel $\mathrm{CR}$ mengalami peningkatan $1 \%$ dan variabel independen konstan artinya struktur modal akan turun sebesar 0.099751 .

\section{Uji Asumsi Klasik}

Uji Normalitas

Uji normalitas menunjukkan variabel independen terdistribusi normal atau tidak.

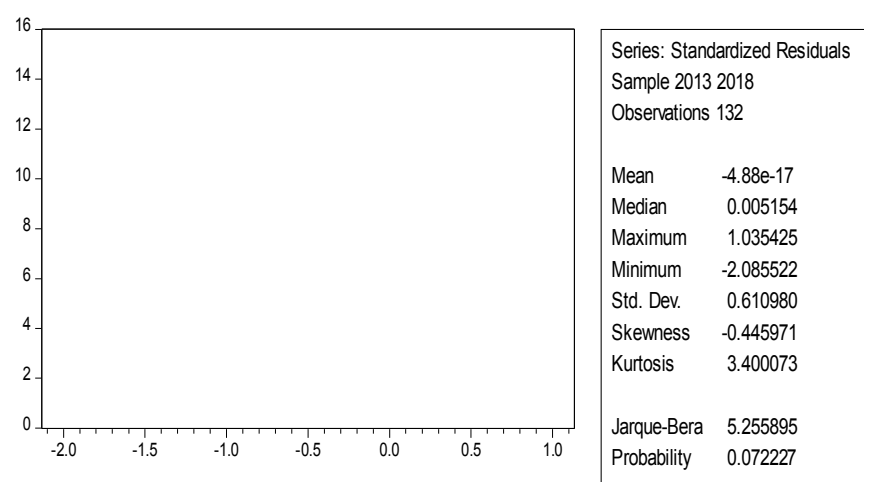

Sumber : Diolah oleh peneliti dari Eviews 10, 2020

Gambar 1. Hasil Uji Normalitas

Berdasarkan gambar 1. uji normalitas menggunakan JarqueBerra dapat dilihat bahwa nilai probabilitas sebesar 0.072227 $>0.05$ maka diambil kesimpulan data terdistribusi normal.

Uji Multikolinearitas

Uji multikolinearitas menunjukkan adanya korelasi pada regresi antar variabel independen. Berikut hasil ujinya:

Tabel 6. Hasil Uji Multikolinearitas

\begin{tabular}{|c|c|c|c|c|c|}
\hline & FAR & ROA & GROWTH & SIZE & CR \\
\hline FAR & 1.000000 & -0.101680 & -0.065372 & -0.119950 & 0.116175 \\
\hline ROA & -0.101680 & 1.000000 & 0.314708 & 0.040382 & -0.043188 \\
\hline $\begin{array}{l}\text { GRO } \\
\text { WTH }\end{array}$ & -0.06537 & 0.314708 & 1.000000 & 0.145163 & -0.092839 \\
\hline SIZE & -0.11995 & 0.040382 & 0.145163 & 1.000000 & 0.142415 \\
\hline CR & 0.116175 & -0.043188 & $3-0.092839$ & 0.142415 & 1.000000 \\
\hline
\end{tabular}

Sumber : Diolah oleh peneliti dari Eviews 10, 2020 
Berdasarkan tabel 6. penelitian ini menggunakan matriks korelasi variabel independen. Dapat dilihat bahwa matriks korelasi diatas tidak lebih dari 0.90. Ditarik kesimpulan bahwa data ini tidak terkena multikolinearitas.

Uji Heteroskedastisitas

Uji heteroskedastisitas menunjukkan ada atau tidaknya perbedaan variance residual dari variabel independen.

Tabel 7. Hasil Uji Heteroskedastisitas

\begin{tabular}{ccccc}
\hline Variable & Coefficient & Std. Error & t-Statistic & Prob. \\
\hline FAR & -3.640846 & 2.479065 & -1.468637 & 0.1444 \\
ROA & 5.820508 & 4.639752 & 1.254487 & 0.2120 \\
GROWTH & -2.592986 & 1.962473 & -1.321284 & 0.1888 \\
SIZE & -0.145873 & 0.119584 & -1.219835 & 0.2248 \\
CR & 0.023023 & 0.125304 & 0.183738 & 0.8545 \\
C & 1.433736 & 1.392432 & 1.029663 & 0.3051
\end{tabular}

Sumber : Diolah oleh peneliti dari Eviews 10, 2020

Berdasarkan tabel 7. penelitian ini memakai uji park nilai probabilitas variabel independen tidak ada yang dibawah 0.05. Sehingga data tersebut tidak terkena heteroskedastisitas.

Uji Autokorelasi

Uji autokorelasi menunjukkan korelasi antar residual satu dengan pengamatan lain.

Tabel 8. Hasil Uji Autokorelasi

\begin{tabular}{cccc}
\hline \multicolumn{3}{c}{ Weighted Statistics } \\
\hline $\begin{array}{c}\text { R-squared } \\
\text { Adjusted R- } \\
\text { squared }\end{array}$ & 0.295446 & Mean dependent var & -0.078248 \\
$\begin{array}{c}\text { S.E. of } \\
\text { regression }\end{array}$ & 0.2886748 & S.D. dependent var & 0.337286 \\
$\begin{array}{c}\text { F-statistic } \\
\text { Prob(F- } \\
\text { statistic) }\end{array}$ & 0.000000 & Sum squared resid & 10.49981 \\
\hline
\end{tabular}

Sumber : Diolah oleh peneliti dari Eviews 10, 2020

Sesuai dengan tabel 8. nilai DW sebesar 1.181113 kurang dari nilai dL dalam tabel DW yaitu 1.6397. Sehingga diambil kesimpulan penelitian ini terkena autokorelasi. Masalah ini dapat diatasi dengan robust coefficient covariances menggunakan metode estimasi Panel Corrected Standard Error (PCSE), ini berguna untuk mengkoreksi standar error yang didapat sehingga masalah autokorelasi menjadi tidak berarti Religi \& Purwanti (2017).

\section{Uji Hipotesis}

Pengujian hipotesis digunakan untuk menguji hipotesis dan mengetahui determinan faktor variabel independen terhadap dependen secara simultan dan parsial dalam penelitian ini.

Uji Statistik F

Uji Statistik F menunjukkan secara keseluruhan variabel independen terdapat pengaruh secara simultan terhadap variabel dependen atau tidak.
Tabel 9. Hasil Uji Statistik F

\begin{tabular}{cccc}
\hline \multicolumn{4}{c}{ Weighted Statistics } \\
\hline $\begin{array}{c}\text { R-squared } \\
\text { Adjusted R- } \\
\text { squared }\end{array}$ & 0.295446 & Mean dependent var & -0.078248 \\
$\begin{array}{c}\text { S.E. of } \\
\text { regression }\end{array}$ & 0.288673 & Sum squared resid & 10.49981 \\
$\begin{array}{c}\text { F-statistic } \\
\text { Prob(F- } \\
\text { statistic) }\end{array}$ & 0.0000000 & Durbin-Watson stat & 1.181113 \\
& & & \\
\hline
\end{tabular}

Sumber : Diolah oleh peneliti dari Eviews 10, 2020

Berdasarkan tabel 9. diketahui bahwa nilai uji $\mathrm{F}$ prob (Fstatistic) sebesar $0.000000<0.05$ maka tolak H0. Bisa diambil kesimpulan semua variabel independen (Struktur Aktiva (FAR), Profitabilitas (ROA), Pertumbuhan Perusahaan (Growth), Ukuran Perusahaan (Size) dan Likuiditas (CR)) secara simultan ada pengaruh signifikan pada Struktur Modal.

Uji Statistik t

Uji statistik $\mathrm{t}$ menunjukkan seberapa jauh variabel independen mempengaruhi secara parsial terhadap variabel dependen.

Tabel 10. Hasil Uji Statistik t

\begin{tabular}{ccccc}
\hline Variable & \multicolumn{1}{c}{ Coefficient } & Std. Error t-Statistic & Prob. \\
\hline C & -0.347111 & 0.335600 & -1.034301 & 0.3030 \\
FAR & -0.949322 & 0.572579 & -1.657975 & 0.0998 \\
ROA & -1.745852 & 0.857364 & -2.036303 & 0.0438 \\
GROWTH & 1.348891 & 0.259959 & 5.188867 & 0.0000 \\
SIZE & 0.018351 & 0.026797 & 0.684825 & 0.4947 \\
CR & -0.099751 & 0.028428 & -3.508848 & 0.0006
\end{tabular}

Sumber : Diolah oleh peneliti dari Eviews 10, 2020

Sesuai dengan tabel 10. hasil dari uji statistik t, yaitu :

1.Struktur Aktiva bernilai koefisien sebesar -0.949322, bernilai negatif. Nilai probabilitas sebesar $0.0998 \geq 0.05$ artinya bahwa Struktur Aktiva memiliki ada negatif dan tidak signifikan terhadap Struktur Modal (DER).

2. Profitabilitas bernilai koefisien sebesar -1.745852 , bernilai negatif. Nilai probabilitas sebesar $0.0438<0.05$ artinya Profitabilitas ada pengaruh negatif dan signifikan terhadap Struktur Modal (DER).

3. Pertumbuhan Perusahaan memiliki nilai koefisien yaitu 1.348891 , bernilai positif. Nilai probabilitas yaitu $0.0000<$ 0.05 artinya Pertumbuhan Perusahaan berpengaruh positif dan signifikan terhadap Struktur Modal (DER).

4. Ukuran Perusahaan bernilai koefisien yaitu 0.018351, bernilai positif. Nilai probabilitas yaitu $0.4947 \geq 0.05$ artinya bahwa Ukuran Perusahaan berpengaruh positif dan tidak signifikan terhadap Struktur Modal (DER). 
5. Likuiditas bernilai koefisien yaitu -0.099751 , bernilai negatif. Nilai probabilitas yaitu $0.0006<0.05$ artinya Likuiditas berpengaruh negatif dan signifikan terhadap Struktur Modal (DER).

\section{Analisis Koefisien Determinasi (R2)}

Analisis koefisien determinasi (R2) dipakai untuk melihat ketetapan antar nilai dugaan dengan data sampel.

Tabel 11. Analisis Koefisien Determinasi

\begin{tabular}{cccc}
\hline \multicolumn{4}{c}{ Weighted Statistics } \\
\hline $\begin{array}{c}\text { R-squared } \\
\text { Adjusted R- } \\
\text { squared }\end{array}$ & 0.295446 & Mean dependent var & -0.078248 \\
$\begin{array}{c}\text { S.E. of } \\
\text { regression }\end{array}$ & 0.288673 & Sum squared resid & 10.49981 \\
$\begin{array}{c}\text { F-statistic } \\
\text { Prob(F- } \\
\text { statistic) }\end{array}$ & 0.000000 & S.D. dependent var & 0.337286 \\
\end{tabular}

Sumber : Diolah oleh peneliti dari Eviews 10, 2020

Berdasarkan tabel 11. diketahui nilai Adjusted R-Squared yaitu 0.267487, ini mengartikan Struktur Aktiva, Profitabilitas, Pertumbuhan Perusahaan, Ukuran Perusahaan dan Likuiditas menjelaskan $26.7487 \%$ variabel Struktur Modal sedangkan $73.2517 \%$ sisanya dijelaskan oleh faktor lain.

\section{Pembahasan}

Pengaruh Struktur Aktiva, Profitabilitas, Pertumbuhan Perusahaan, Ukuran Perusahaan dan Likuiditas terhadap Struktur Modal

Berdasarkan hasil perhitungan Uji statistik $F$, nilai uji $F$ probabilitas (F statistic) sebesar 0.000000. artinya nilai probabilitas $0.000000<0.05$, maka tolak H0. Mengartikan bahwa secara bersama-sama Struktur Aktiva, Profitabilitas, Pertumbuhan Perusahaan, Ukuran Perusahaan dan Likuiditas berpengaruh signifikan terhadap Struktur Modal.

\section{Pengaruh Struktur Aktiva terhadap Struktur Modal}

Sesuai dengan hasil perhitungan uji statistik t, Struktur Aktiva bernilai koefisien yaitu -0.949322 , nilai probabilitas sebesar $0.0998 \geq 0.05$ artinya Struktur Aktiva memiliki pengaruh negatif dan tidak signifikan terhadap Struktur Modal. Mengartikan bahwa besar atau kecilnya struktur aktiva tidak berdampak terhadap hutang. Perusahaan dengan perbandingan aset lancar lebih rendah dari aset tetap akan menurunkan hutang yang dimilikinya. Sesuai dengan Pecking Order Theory yang dikemukakan oleh Myres (1984) dalam Noor Saarani \& Shahadan (2013) berpendapat bahwa perusahaan akan terdorong untuk menggunakan pendanaan yang dimilikinya sehingga menghindari adanya hutang. Hal ini didukung dengan penelitian Sarah (2018) dan Niztiar \& Muharam (2013) yang berkesimpulan Struktur Aktiva memiliki pengaruh negatif dan tidak signifikan terhadap Struktur Modal.

\section{Pengaruh Profitabilitas terhadap Struktur Modal}

Sesuai dengan hasil perhitungan uji statistik $t$, Profitabilitas bernilai koefisien yaitu-1.745852, nilai probabilitas sebesar
$0.0438<0.05$ artinya Profitabilitas berpengaruh negatif dan signifikan terhadap Stuktur Modal. Mengartikan Profitabilitas yang tinggi akan membuat hutang perusahaan akan menurun. Perusahaan dengan laba besar memanfaatkan pendanaan dari laba kotor perusahaan ketimbang berhutang. Hal ini akan selaras pada Pecking Order Theory yang berpendapat perusahaan terdorong memilih dana dari dalam perusahaan sebelum berhutang. Hal ini didukung dengan penelitian Ariani \& Wiagustini (2017), Djazuli et al. (2019) dan Zerriaa \& Noubbigh (2015) yang berkesimpulan Profitabilitas memiliki pengaruh negatif dan signifikan terhadap Struktur Modal.

\section{Pengaruh Pertumbuhan Perusahaan terhadap Struktur Modal}

Berdasarkan hasil perhitungan uji statistik t, Pertumbuhan Perusahaan bernilai koefisien yaitu 1.348891, nilai probabilitas yaitu $0.0000<0.05$ artinya pada Perusahaan yang tumbuh memiliki pengaruh positif dan signifikan terhadap Struktur Modal. Mengartikan bahwa Pertumbuhan Perusahaan yang tinggi akan mendorong perusahaan untuk berhutang. Ketika dana internal kurang terpenuhi maka perusahaan terdorong untuk menggunakan alternatif yaitu sumber pendanaan eksternal. Dalam Packing Order Theory yang menyatakan perusahaan cenderung memakai sumber dari internal. Akan tetapi, perusahaan yang memiliki pertumbuhan tinggi melakukan peningkatan aktiva sehingga mendorong perusahaan untuk berhutang Maryanti (2016). Perusahaan yang mengandalkan modal dari luar perlu memperharikan risiko yang didapat. Hal ini didukung penelitian Ariani \& Wiagustini (2017) yang berkesimpulan Perusahaan yang mengalami pertumbuhan akan memiliki pengaruh positif terhadap Struktur Modal.

\section{Pengaruh Ukuran Perusahaan terhadap Struktur Modal}

Berdasarkan perhitungan uji statistik $t$, maka menghasilkan bahwa Ukuran Perusahaan memiliki nilai koefisien sebesar 0.018351 , nilai probabilitas sebesar $0.4947 \geq 0.05$ artinya Ukuran Perusahaan berpengaruh positif dan tidak signifikan terhadap Struktur Modal. Mengartikan bahwa ukuran perusahaan yang besar akan cenderung menggunakan modal dari luar perusahaan. Dalam Trade-Off Theory mengasumsikan bahwa perusahaan yang berukuran besar akan terkena pajak yang besar pula sehingga perusahaan akan memilih untuk berhutang karena bunga dari hutang tersebut dapat mengurangi beban pajak yang dibayarkan oleh perusahaan Batubara et al. (2017). Hal ini didukung penelitian Aditya \& Imo Gandakusuma (2015), dan Dakua (2019) berkesimpulan Ukuran Perusahaan berpengaruh positif dan signifikan terhadap Struktur Modal.

\section{Pengaruh Likuiditas terhadap Struktur Modal}

Berdasarkan hasil perhitungan uji statistik t, Likuiditas bernilai koefisien yaitu -0.099751 , nilai probabilitas yaitu $0.0006<0.05$ artinya Likuiditas ada signifikan dan pengaruh negatif terhadap Struktur Modal. Mengartikan ketika likuiditas tinggi pada perusahaan, maka perusahan tersebut akan memanfaatkan penggunaan dana yang dimiliki oleh perusahaan terlebih dahulu. Sebagaimana dalam Pecking Order Theory Myers (1984) dalam Noor Saarani \& Shahadan (2013) berpendapat likuiditas tinggi pada suatu perusahaan, maka akan memicu perusahaan tersebut memakai dana yang dimilikinya untuk kegiatan operasional sebelum mengambil 
keputusan untuk berhutang. Hal ini didukung penelitian Thi Phuong Nhung et al. (2017) dan Aditya \& Imo Gandakusuma (2015) berkesimpulan Likuiditas terhadap Struktur Modal terdapat pengaruh negatif.

\section{Pembahasan Model Koefisien Determinasi}

Pada adjusted R-squared penelitian ini menghasilkan 26.7\% pada hasil model koefesien determinan.

Sedangkan penelitian yang dilakukan Aditya \& Imo Gandakusuma (2015) berjudul Analisis Faktor Determinasi yang Mempengaruhi Struktur Modal Perusahaan yang Terdaftar di Sektor Properti dan Real Estate dan Kontruksi Bangunan dalam Bursa Efek Indonesia Periode 2011-2014 menunjukkan nilai adjusted R-square sebesar $87,7 \%$ dengan variabel pembentuk struktur modal yaitu profitability, size, tangibility, liquidity, asset turnover, percentage change in total asset dan percentage change in sales. Variabel yang diteliti penelitian diatas merupakan bagian dari variabel keuangan kinerja perusahaan.

Penelitian yang dilakukan Wardani, Suhendro, \& Samrotun (2017) berjudul Dimensi Struktur Modal Pada Perusahaan Property dan Real Estate yang Terdaftar di BEI Periode 2016-2017 menunjukkan nilai adjusted R-squared sebesar 96.3\% dengan variabel pembentuk struktur modal yaitu profitabilitas (ROA), struktur aktiva, likuiditas, aktivitas (TATO). Variabel yang diteliti penelitian diatas merupakan bagian dari variabel keuangan kinerja perusahaan.

Penelitian yang dilakukan Ranitasari \& Maftukhah (2018) berjudul The Determinan of Capital Structure on Property and Real Estate Company Period 2012-2016 menunjukkan nilai adjusted R-squared sebesar $83.7 \%$ dengan variabel pembentuk struktur modal yaitu profitability, liquidity, asset growth, firm size dan asset structure. Variabel yang diteliti penelitian diatas merupakan bagian dari variabel keuangan kinerja perusahaan.

Penelitian yang dilakukan Dewi, Suci, Ngurah, \& Martin (2019) berjudul Pengaruh Profitabilitas dan Likuiditas Terhadap Strruktur Modal Perusahaan Propery dan Real Estate di Bursa Efek Indonesia menunjukkan nilai adjusted R-squared sebesar $92.5 \%$ dengan variabel pembentuk struktur modal yaitu profitabilitas dan likuiditas. Variabel yang diteliti penelitian diatas merupakan bagian dari variabel keuangan kinerja perusahaan.

Dari hasil perbandingan diatas ditemukan kesimpulan bahwa penelitian ini masih kurang baik, dan untuk mencari model yang baik dari variabel pembentuk struktur modal perusahaan properti dan real estate disarankan mencari model dari variabel keuangan kinerja perusahaan tidak hanya dalam penelitian ini agar nilai adjusted Rsquarednya tinggi sehingga dapat menjelaskan dengan baik variabel pembentuk struktur modal.

\section{Simpulan}

Hasil pengujian hipotesis membuktikan bahwa 5 determinan yang diteliti secara bersama-sama memiliki pengaruh signifikan terhadap Struktur Modal. Diperoleh nilai koefisien determinasi sebesar $26.7 \%$ dari 5 determinan yang diteliti terhadap Struktur Modal sedangkan 73.3\% sisanya dijelaskan oleh variabel lain.
Penelitian ini memiliki rentan yang cukup panjang yaitu 6 tahun, penelitian ini menemukan beberapa temuan yaitu : pertama, terdapat 3 variabel independen yang signifikan yaitu profitabilitas, pertumbuhan perusahaan dan likuiditas, dari 3 variabel tersebut maka variabel pertumbuhan perusahaan adalah variabel paling dominan pengaruhnya terhadap struktur modal. Kedua, indikator variabel yang digunakan untuk membentuk variabel struktur modal perusahaan properti dan real estate yang tepat dijadikan model yang baik untuk menjawab fenomena struktur modal adalah variabel keuangan kinerja perusahaan.

\section{Referensi}

ames Van Horne, \& Jr, J. W. (2012). Prinsip-prinsip Manajemen Keuangan (Edisi 13). Jakarta: Salemba Empat.

Jogiyanto. (2009). Sistem Informasi Manajemen. Yogyakarta: Andi.

Riyanto. (2011). Dasar-dasar Pembelanjaan Perusahaan (Edisi Keempat). Yogyakarta: BPFE.

Sugiyono. (2014). Metode Penelitian Kuantitatif, Kualitatif dan R\&D. Bandung: Alfabeta.

Sutrisno. (2013). Manajemen Keuangan Teori Konsep \& Aplikasi. Yogyakarta: Ekonisia.

Aditya, R., \& Imo Gandakusuma. (2015). Analisis Faktor Determinasi Yang Mempengaruhi Struktur Modal Perusahaan Yang Terdaftar Di Sektor Properti Real Estate Dan Konstruksi Bangunan Dalam Bursa Efek Indonesia Periode Tahun 2011 - 2014.

Ariani, N. K. A., \& Wiagustini, N. L. P. (2017). Faktor-Faktor yang Mempengaruhi Struktur Modal Perusaan Property \& Real Estate yang Terdaftar di BEI. E-Jurnal Manajemen Universitas Udayana, 6(6), 3168-3195.

Astuti, R. A., Ritonga, K., \& A, A. A. (2014). Pengaruh Pertumbuhan Aset, Profitabilitas, dan Pertumbuhan Penjualan Terhadap Struktur Modal Pada Perusahaan Real Estate Dan Properti Yang Terdaftar Di Bursa Efek Indonesia Periode 2010-2012. 1(2), 1-15.

Batubara, R. A. P., Topowijono, \& Z.A., Z. (2017). Pengaruh Struktur Aktiva, Ukuran Perusahaan, dan Profitabilitas terhadap Struktur Modal (Studi pada Perusahaan Makanan dan Minuman yang Terdaftar di Bursa Efek Indonesia Tahun 2012-2015). Jurnal Administrasi Bisnis (JAB), 50(4), 1-9. Diambil dari http://administrasibisnis.studentjournal.ub.ac.id/index.php/jab/article/v iew/2024

Dakua, S. (2019). Effect of determinants on financial leverage in Indian steel industry: A study on capital structure. (September 2018), 427-436. https://doi.org/10.1002/ijfe.1671

Dewi, R., Suci, M., Ngurah, A. A., \& Martin, Y. (2019). Pengaruh Profitabilitas dan Likuiditas Terhadap Struktur Modal Perusahaan Sektor Property dan Real Estate di Bursa Efek Indonesia. 5(2), 140 147.

Djazuli, A., Choiriyah, C., \& Anggraini, N. S. (2019). The Impact of Company Size, Asset Structure and Profitability on Capital Structure of the Automotive Sector Companies Listed in Indonesia Stock Exchange. Journal of Management Research, 11(2), 55. https://doi.org/10.5296/jmr.v11i2.14473

Herlisnawati, D., Insani, B., \& Indrayono, Y. (2015). Analisis Faktor-Faktor Yang Mempengaruhi Struktur Modal Pada Perusahaan Foods and Beverages Yang Terdaftar di Bursa Efek Indonesia Periode 20112015.

Maryanti, E. (2016). Analisis Profitabilitas, Pertumbuhan Perusahaan, Pertumbuhan Penjualan, dan Struktur Aktiva Terhadap Struktur Modal Pada Perusahaan Sektor Industri Barang Komsumsi Yang Terdaftar di Bursa Efek Indonesia. 1(2014), 143-151.

Mufidah, Ulupui, I. G. K. A., \& Prihatni, R. (2018). Pengaruh Profitabilitas, Likuiditas, dan Risiko Bisnis Pada Struktur Modal Perusahaan Properti dan Real Estate di Bursa Efek Indonesia. 129-138.

Niztiar, G., \& Muharam, H. (2013). Analisis Faktor-Faktor Yang Mempengaruhi Pertambangan Yang Terdaftar Di Bursa Efek Indonesia Periode 2008-2011. 2, 1-8.

Noor Saarani, A., \& Shahadan, F. (2013). The determinant of capital structure of SMEs in Malaysia: Evidence from enterprise 50 (E50) SMEs. Asian Social Science, 9(6), 64-73. https://doi.org/10.5539/ass.v9n6p64 
Novari, P. M., \& Lestari, P. V. (2016). PENGARUH UKURAN PERUSAHAAN, LEVERAGE, DAN PROFITABILITAS TERHADAP NILAI PERUSAHAAN PADA SEKTOR PROPERTI DAN REAL ESTATE. 5(9), 5671-5694.

Prayogo, P. (2016). Analisis Faktor-faktor Yang Mempengaruhi Struktur Modal Pada Perusahaan Manufaktur Yang Terdaftar di Bursa Efek Indonesia.

Putri, R. E. K. A. (2014). Pengaruh Struktur Aktiva Dan Tingkat Pertumbuhan Penjualan Terhadap Struktur Modal Perusahaan Manufaktur Yang Terdaftar Di Bursa Efek Indonesia. 1(2), 216-231.

Ranitasari, R., \& Maftukhah, I. (2018). The Determinants of Capital Structure on Property and Real Estate Company Period 2012-2016. Management Analysis Journal, 7(4), 469-480. https://doi.org/10.15294/maj.v7i4.23499

Religi, S., \& Purwanti, D. (2017). ANALISIS PERBANDINGAN PENGARUH MODAL DAN TENAGA KERJA TERHADAP PERTUMBUHAN EKONOMI ANTAR TIPE KLASIFIKASI KABUPATEN / KOTA. 66-77.

Rifai, M. H. (2015). Pengaruh Risiko Bisnis, Pertumbuhan Perusahaan, Ukuran Perusahaan dan Struktur Aktiva Terhadap Kebijakan Hutang Pada Perusahaan Sektor Property and Real Estate Yang Terdaftar di Bursa Efek Indonesia.

Rosyid, A., Aziz, A., \& Triwahyuningtyas, N. (2010). Analisis Kebijakan Struktur Modal Perusahaan Subsektor Properti dan Real Estate. 601615.

Salempang, L. E., Sondakh, J. J., \& Pusung, R. J. (2016). PENGARUH RETURN ON ASSET , DEBT TO EQUITY DAN PERTUMBUHAN PENJUALAN TERHADAP NILAI PERUSAHAAN PADA SEKTOR
REAL ESTATE DAN PROPERTY YANG TERDAFTAR DI BEI TAHUN 2013-2014 INFLUENCES OF RETURN ON ASSETS , DEBT TO EQUITY AND SALES GROWTH OF FIRM VALUE SECTOR. 16(03), 813-824.

Sarah, A. (2018). Faktor-Faktor yang Mempengaruhi Struktur Modal Pada Perusahaan Properti dan Real Estate yang Terdaftar di Bursa Efek Indonesia.

Thi Phuong Nhung, N., Phuong Lien, N., \& Thi Thu Hang, D. (2017). International Journal of Economics and Financial Issues Analyze the Determinants of Capital Structure for Vietnamese Real Estate Listed Companies. International Journal of Economics and Financial Issues, 7(4), 270-282. Diambil dari http:www.econjournals.com

Tijow, A. P., Sabijono, H., \& Tirayoh, V. Z. (2018). PENGARUH STRUKTUR AKTIVA DAN PROFITABILITAS TERHADAP STRUKTUR MODAL PADA PERUSAHAAN SEKTOR INDUSTRI BARANG KONSUMSI YANG TERDAFTAR DI BURSA EFEK INDONESIA. 13(3), 477-488.

Wardani, G., Suhendro, \& Samrotun, Y. C. (2017). DIMENSI STRUKTUR MODAL PADA PERUSAHAAN PROPERTY DAN REAL ESTATE YANG TERDAFTAR DI BEI PERIODE 2016-2017.

Wulandari, S., \& Zulhaimi, H. (2017). Pengaruh Profitabilitas terhadap Corporate Social Responsibility Pada Perusahaan Manufaktur dan Jasa yang Terdaftar di Bursa Efek Indonesia Corporate social responsibility atau Pengolahan Lingkungan Hidup ( Proper ) merupakan Program Kementrian Lingkungan. 2(2), 1477-1488.

Zerriaa, M., \& Noubbigh, H. (2015). Determinants of Capital Structure: Evidence from Tunisian Listed Firms. International Journal of Business and Management, 10(9), 121-135. https://doi.org/10.5539/ijbm.v10n9p121. 